\title{
The role of landscape design in Smart Cities
}

\author{
Skirmante Mozuriunaite, Vilnius Gediminas Technical University, Faculty of Architecture
}

\begin{abstract}
Smart cities are not a new phenomenon and it is an interdisciplinary definition that became a popular labelling for modern cities. However, there a is surprisingly little academic research in urban design and planning field that discusses this phenomenon. Smart cities definition is similar to intelligent, creative, sustainable or liveable cities which appears to be considered as a part of a play with words. In most of the technological and social science articles smart cities refer to a smart urban management and development via technologies and infrastructure. Based on the scientific literature overview, there are several factors affecting the city smartness, such as technology, people and communities, economy governance, planning and infrastructure. Overall there is a little information and research on urban design principles and tools in the smart city's creation and contribution to its smartness. The most important thing is to clarify the urban design, planning and landscape design role importance to a smart city context and vice versa. The aim of this paper is to overview the smart cities concept from urban design perspective to find and highlight the important touch points, relation and role of urban design, planning and landscape design in smart cities creation. This would lead to the robust principles for smart European cities that would enable to achieve sustainable development, efficient urban growth and a better urban landscape.
\end{abstract}

Keywords: smart city, smart coding, sustainable city, urban development, landscape, environmental

\section{Introduction}

The definition of the "smart cities" originally dates the beginning of the 19th century. Writers this definition used to describe a newly build cities with a powerful self-governance, in the west of the United States of America. Despite the early use of timeless term its use shifted to the end of the 20th century. The definition was welcome as a new term for the present urbanisation processes and government control of society and industry in general [10].

Is there an answer to a question what the is a smart city? Even today, there is no clear agreement on the term just several definitions. Smart city definition more than 20 years ago, described the future cities as "global network cities" with interactive "economic nodes" linked to the airports, highways, and other communications [10]. The other term of smart cities states smart cities are defined by the proper management, good residents' entrepreneurship, with multifunctional uses and suitable contemporary facilities.

Nowadays the interdisciplinary and social studies definition of the smart cities link with the digital technologies, software and applications that help to create, manage and control the modern city infrastructure. However, the biggest challenge at this point is the practical issues, how to develop a "smart city," on the basis of the todays city by combining interdisciplinary principles and tools that could activate the infrastructure, but at the same time could benefit to the urban, spatial and landscape structures.

The recent interdisciplinary literature on smart cities, their governance, infrastructure, residents and urban development generate a lot of discussions and attention. At this point we could ask the question is if the smart cities in general and their performance is the focus of the discussion or the technological aspect. The concern on the smart cities definition raises from the dynamic development of digital technologies and interconnection of the mutual scientific disciplines. The main discussions and articles on the small cities are mostly technologically driven, where the main principles of the city and design tool are set back. But how can you create smart city without urban and landscape design and architecture. To bridge the gap between digital and natural and urban environment, the collaboration and integrated design tools must be used in order to achieve functioning and completely smart city concept [14].

The purpose of this paper is to overview the definitions, concept and trends of smart city, urban design and landscape design role in their creation and development. Overview the design principles and scope of the design tools that should be incorporated and emphasized in a smart city creation via urban design and urban landscape, such as future telecommunication, innovative systems ecosystems, etc.

\section{The main elements of smart city}

The simplified definition of a city would be a complex social and interdisciplinary system. However, it is more complexed. According the B. Godal (1987) "/./ any urban form but applied particularly to large urban settlements"; "Originally the term indicated certain socio-political functions and implied predominance in trace-commercial relations" [11]. Lombardi et al. (2012) explains this complexity of interactions between individuals by 
Smart city characteristics. Construction by Vanolo, A. 2014.

\begin{tabular}{|c|c|}
\hline Characteristics & \\
\hline Smart economy & $\begin{array}{l}\text { An aspect which the authors link to a spirit of innovation, entrepreneurialism, } \\
\text { flexibility of the labour market, integration in the international market and the } \\
\text { ability of transform }\end{array}$ \\
\hline Smart mobility & $\begin{array}{l}\text { Referred to local and supra-local accessibility, viability of ICT's, modern, } \\
\text { sustainable and safe transport }\end{array}$ \\
\hline Smart governance & $\begin{array}{l}\text { Related to participation in decision-making processes, transparency of } \\
\text { governance systems, availability of public services and quality of political } \\
\text { strategies. }\end{array}$ \\
\hline Smart environment & $\begin{array}{l}\text { Understood in terms of attractiveness of natural conditions, lack of pollution and } \\
\text { sustainable management of resources. }\end{array}$ \\
\hline Smart living & $\begin{array}{l}\text { Involving the quality of life, imagined and measured in terms of availability of } \\
\text { cultural and educational services, tourist attractions, social cohesion, healthy } \\
\text { environment, personal safety and housing. }\end{array}$ \\
\hline Smart people & $\begin{array}{l}\text { Linked to the level of qualification of human and social capital flexibility, } \\
\text { creativity, tolerance, cosmopolitanism and participation in public life. }\end{array}$ \\
\hline
\end{tabular}

the variety and unpredictability [21]. Cities are areas where there are different, but inseparable ecosystems, communications and other systems exist. This approach is confirmed by other authors who claim that the city as a political, socioeconomic and cultural area [24] with a range of economic, territorial, political, religious, connoisseur and linguistic ties complex system in a given territory [4].

The scientific literature and international practice do not have a single smart city definition. By explaining the content of smart cities or regions, it is necessary to identify the main elements of the urban and regional content structure. The European Council of Self-Governing and Regional Authorities (2005), report points out that internal structure of European countries, their regions and cities are very diverse and it is not possible to find an identical structure. Therefore, their functions performants differ too. Nevertheless, the overall level of development is determined by the results of the development of each structural element and the synergy between them.

One of the first attempts to analyse smart cities was considered by Lipman et al. (1986) in book "Teleports and the Intelligent City" [20]. An intelligent city by that time was then understood as a digital city, with the core was teleports. The following studies by Bruhns [5] did not change the concept and definition of smart city. By analysing the environmental smartness, author also emphasized the importance of information technology [16].

Komninos (2011), differently from the other researchers states that present concept of spatial smartness of the city, describes the ability of the community to use its smartness capital, institutions and material infrastructure to solve problems and cope with the challenges. According to the author, the spatial smartness of the city raises from the three types of smartness: the ingenuity, creativity and smartness capital of the residents; the collective city, its institutions and the social capital of smartness; artificial smart society and urban infrastructure, as well as virtual environment and intellectuals [18].

According to Gruen (2013), in the context of the smart cities, the spatial intelligence covers all components needed for an effectively manage in order to achieve goals of high quality of life in the long term (this is equated with the ability to quickly recover) [12]. The author writes about information and cognitive processes: collecting and processing information in real-time, forecasting, learning, collective intelligence and distributed problem solving. Here it is clearly illustrated that the Information Communication Technologies (ICT) is playing an important role in realising the abovementioned subjects. Despite the ICT use, the spatial smartness can be understood through the urban design tools, use of geographic information systems (GIS), 3D modelling [24] or even spatial communication ability [24] and other similar things. Thus, it is clearly undeniable the essence of the inevitability of interconnecting both, information technology and the geographical layout of the smart city.

Alberto Vanolo (2014) states, that discussion and debates on the smart city are compared to the „historic urban imaginaries “, that can occur and emerge from the sustainable city and smartinformation city concept [1]. These concepts, sustainable - green city and information - smart city are powerful concepts provoking the ideas and thinking on the political choices, economic drivers and triggers that accumulate the new types of businesses and new approaches such as restructuration to the eco-state [13].

In general, smart city concept is considered as very optimistic and generic concept of the future. Despite the fact, that there is no consensus or clear agreement on the concept definition, [1;9]. and other authors by analysing smart cities distinguish 
six smart city characters, urban smartness indicators, such as: smart economy, smart mobility, smart governance, smart environment, smart living and smart people [23].

The urban smartness classification above listing the six characteristics for defining the smart cities from generic, interdisciplinary approach are discussed in scientific literature on smart city [21]. Based on these characteristics it is easy to evaluate cities, however, there are way much more indicators that should be consider by evaluating the degree of smartness in chosen medium or large side cities [1].

\section{Importance of smartness in Urban Design context}

United Nations (2014) states, that todays our cities are facing the situation when more than $50 \%$ of human population is living in cities rather than villages. By the year 2050, there will be more than $70 \%$ of people living metropolitan and large cities. Rapid urbanisation processes are becoming more dynamic in many parts of the world, especially in developing countries. The development and growth of largest cities in around the world raises many challenges such as inappropriate waste management, resource insecurity, air pollution, traffic congestion, health issues, lack of decent housing, inadequate and insufficient public infrastructure, social and economic problems. This implies a great need of managing these processes in order to contribute to the sustainable development and making a better living conditions in the future. The search of modern cities solutions becomes complicated due to their unique management system, multiple structure of interest groups, high degree of interconnectivity and interdependence, social and political complexity. Due to such a high complexity and interrelations of the cities issues, the problem solutions become highly complexed.

According to Sinkiene (2017), in order to reveal the essence and content of the smart city concepts, it is needed to define meaning and content of complex concept elements such as: the "city", "region," smartness"[25]. Smartness is the property of subject, which implies the ability to adapt quickly to the environment in the broadest sense.

Perception of successful development and competition in the global marketplace is a prerequisite for a successful regional and urban development. Despite the modern planning and management concepts, over a decade, new regional and urban development management solutions are being sought. The traditional growth and development theories of the 21 st Century explaining and justifying typical trends in the development of society, economy and other areas of life are no longer suitable. New approaches and theories being introduced, explaining these processes and highlighting the close connection with geography and economy. The emphasis is placed not only on the role of human capital and innovation, but also on the agglomeration of institutions, distance and work place [25].

Due to the intensive use of smartness concept in recent decade in the context of social and territorial systems, the implementation of the concept appears to raise some difficulties. Despite that, many European countries, their regions and cities are intensively developing and implementing smart areas, regional and smart urban development strategies. The notion in absence of universal concepts it is important to understand the smart city definition in regions as subnational and territorial systems in the context of their development by emphasising the most important elements of their content and characteristics.

Moving from buildings to districts with a net zero energy concept required holistic integrated approach, in which all the aspects of "green" are considered such as smart technologies, mobility, etc., [17]. Smart ground could be the basis of "smart grid" and "smart city" as part of an efficient energy management system and district in conjunction with power generation and energy demand [19].

The classical urban design principles easily collate with Maslow's hierarchy of human needs [22]. While rethinking smart city strategies from urban and landscape design perspectives taking in to account ICT's, political, economic and social and innovation influence it is important to find the interrelation and interconnections to make smart cities operate based not only on technological, social or economic aspects, but interdisciplinary approach. Based on the existing classification and design principles the table 2 illustrates the smart city design considerations along the classical urban design approach.

Smart city design consideration is common to the urban design approach of environmental sustainability and cities resilience, which is debated during past decade. The interdisciplinary questions that architects are trying to find answers to form the 19th century is still relevant today. Questions such as waste reduction, pollution, mobility, renewable energy and its management, natural elements protection are hard to answer and to find the tools how to handle and manage them. The key role of Urban and Landscape design in the creation of the smart city is based on the merge of technological aspects along with the physical city including its residence and public spaces, politics, economy, ecology, etc. Smart technologies (ICT's) combines with urban design principles and strategies could be a great tool for a proper coordination and management of complex issues. The table 2 Smart city design considerations based on the classical 
Smart city design considerations based on the classical urban design approach.

Construction by Koutra S. (2016), Punter J. and Carmona M. (1997).

\begin{tabular}{|c|c|c|}
\hline $\begin{array}{l}\text { Maslow hierarchy } \\
\text { of human need }\end{array}$ & $\begin{array}{l}\text { Urban Design and Landscape } \\
\text { Design considerations }\end{array}$ & $\begin{array}{c}\text { Smart City (Smart Ground) } \\
\text { design considerations }\end{array}$ \\
\hline $\begin{array}{c}\text { Physiological } \\
\text { (food, shelter, health) }\end{array}$ & $\begin{array}{l}\text { Adequate accommodation, utilities } \\
\text { and services } \\
\text { Comfort } \\
\text { Ecologically sound and stable }\end{array}$ & $\begin{array}{c}\text { Density (Residential and Population) } \\
\text { Central to the urban planning of a district: } \\
\text { Economise land use. } \\
\text { Ecology: waste reduction } \\
\text { Climate (and Micro-climate) } \\
\text { Natural element management }\end{array}$ \\
\hline $\begin{array}{l}\text { Safety and security } \\
\text { (protection from danger, } \\
\text { pollution, privacy) }\end{array}$ & $\begin{array}{l}\text { Road safety } \\
\text { Surveillance } \\
\text { Privacy } \\
\text { Accessibility } \\
\text { Permeability } \\
\text { Robustness }\end{array}$ & $\begin{array}{l}\text { Multi- energy systems and renewable energy } \\
\text { Importance at its planning and design } \\
\text { Proximity: proximity of services and facilities } \\
\text { for the site } \\
\text { Compactness: crucial to reduce energy } \\
\text { consumption. } \\
\text { Mobility: transport efficiency } \\
\text { Limit displacements and car dependency, }\end{array}$ \\
\hline $\begin{array}{c}\text { Affiliation } \\
\text { (belonging, community) }\end{array}$ & $\begin{array}{c}\text { Community facilities } \\
\text { A sense of identity/place } \\
\text { Legibility } \\
\text { Visual appropriateness }\end{array}$ & $\begin{array}{l}\text { Potential of Natural Resources } \\
\text { Orientation: spatial district's urban pattern }\end{array}$ \\
\hline $\begin{array}{c}\text { Esteem } \\
\text { (status and recognition) }\end{array}$ & $\begin{array}{c}\text { Ownership } \\
\text { Individuality, belonging }\end{array}$ & - \\
\hline $\begin{array}{l}\text { Self-actualisation } \\
\quad \text { (creativity) }\end{array}$ & $\begin{array}{c}\text { Opportunities for personalisation and } \\
\text { participation in design } \\
\text { Variety }\end{array}$ & $\begin{array}{c}\text { Functional Mixing } \\
\text { Functional autonomy } \\
\text { Hybridization of technologies, }\end{array}$ \\
\hline $\begin{array}{c}\text { Cognitively aesthetic } \\
\text { (intellectual and sensual } \\
\text { stimulation) }\end{array}$ & $\begin{array}{c}\text { Cultural/recreational opportunities } \\
\text { Quality townscape and landscape } \\
\text { Richness }\end{array}$ & Jold \\
\hline
\end{tabular}

Environmental and landscape design elements of the Smart city.

Construction by Hung P. (2017).

\begin{tabular}{|c|c|}
\hline Characteristics & Design elements \\
\hline Vertical green & $\begin{array}{l}\text { The potential of growing food using a base of unconventional water resources to } \\
\text { sustain long term and new generation of water efficient greenhouses. }\end{array}$ \\
\hline Water energy & $\begin{array}{l}\text { - } \text { Water recycling and desanitation, treatment. } \\
\text { An autonomous supply of heat and also of clear water, that is connecter to } \\
\text { - } \text { Humilding and purifies its residual grey water. } \\
\text { - } \text { Solar thermal energy collection. } \\
\text { - } \text { Thermal and fluid dynamics. } \\
\text { - } \text { Passive cooling. } \\
\end{array}$ \\
\hline Water saving & $\begin{array}{l}\text { High-tech solutions for water and chemical crop protection irrigation of crops } \\
\text { outdoors. }\end{array}$ \\
\hline Energy saving & $\begin{array}{ll}\text { - } & \text { Energy convertion } \\
\text { - } & \text { Solar energy collection } \\
\text { Seasonal energy storage. }\end{array}$ \\
\hline Natural ventilation & Ventilation concepts to cool the buildings down, use wind directions. \\
\hline Technology approach & $\begin{array}{l}\text { - } \text { Consume only the essential amount of water. } \\
\text { - } \text { Combining energy saving methods. } \\
\text { - } \text { Improve recourses and use control. } \\
\text { henewable energy resources (geothermal, wind and solar, cool water and } \\
\text { heat pump, wind turbines, photovoltaic panels). }\end{array}$ \\
\hline
\end{tabular}


urban design approach clearly illustrates the absence of certain elements in smart cities, that becomes not relevant for the residents or smart communities due to the ICT's and technological paradigms change.

The technological change that shifted and changed classical function to the digital functions, eliminates the meaning of the place to a certain extent which links back to the absents of the esteem as ownership and individuality in a smart city community. Therefore, we could clearly state that digital technologies to a certain extent eliminate individuality and grounds smartness based on the smart communities. In connection to the individuality the absence of the cognitive aesthetics as quality townscape, landscape and richness refers to the ICT's mobility management and accessibility but not the qualitative approach. Which is why the smart city characteristics being so generic managing only the micro processes in comparison the urban design considerations are the macro scale of cities.

Therefore, the issue arises in urban and landscape design fields become generic, answering the questions related to the cities and regions sustainability levels, user friendly innovative economies that could easily operate in present reallife environments [15].

\section{Smarter City consideration based on the Landscape design}

Landscape design and landscape urbanism today are understood as an interdisciplinary practice in general meaning today are powerless by facing urban realities. However, it managed to emerge and change towards a perception for dealing with strategic, contemporary problems of the urban structure [7]. The majority of contemporary problems relate to the environmentally responsive design, resource efficiency, technologies, and ability to design future cities with quality for the prospective urban communities [15]. By these aspects we see a lot of concepts and strategies are "going greener" and "getting smarter", innovationdriven, trying to become more sustainable. However, the sustainability definitions are more extensive definition than "green". It addresses the long-term goals in the field of built environment, seeking the solutions in order to protect and maintain the balance between ecology and economic aspects [15].

The definition of "sustainable development" appear around the 1980s, but it was a broader term including economic, agricultural, industrial, technological and other aspects [14]. Later, by the World Commission on Environment and Development the sustainable development was defined as [6]: "Sustainable development is development that meets the needs of the present without compromising the ability of future generations to meet their own needs" [23].
Smart technological incorporation of the ICT's along with the design principles could a next step forward in to the smart community with technical innovations that could implement the technologies and approach on water saving, green energy management, natural ventilation and system integration. This would lead the communities and cities towards progressive approach to a sustainable design, greenhouses and smart green [15]. Environmental and landscape design elements of the Smart city in the table 2 illustrates the principles by which the sustainability could be achieved combining it with a design principles and ICT technology. According to Grabys (2014), implementation of a new smart city principles is based on ICT's sensor use via computation in urban infrastructures together with smart devices in order to achieve greater sustainability [8].

The natural landscape, is considered as the lens, which reflects the tools applied on the smart city. On other hand, the respectation of the natural environment and landscape could become as a design tool and indicator of the sustainable growth. According to Fakiri (2016), these sustainability indicators could control the increasing balance between the natural space and the urban fabric [7]. However, it is not enough to have the indicators, the smart ICT technologies need an implementation which could emerge from the society as "smart city initiatives" [2].

To sum up, the "smart city" concept and "green", "sustainable" concept in landscape design are used for a smart city development. The tools that are used in landscape design to create and develop smart city are on the basis of sustainable materials, ICT's, smart technologies, natural resources, etc. Therefore, the landscape design role in smart city concept and its creation is towards more sustainable cities by improving citizens living environment.

\section{Conclusions}

With the concept of being "smart" cities are experiencing a lot of pressure to become a "smart city". According to Glasmeier (2016), cities are trying to implement and add additional elements to the definition of being "smart" by extending it beyond technological aspects [10]. However, this phenomenon is the result of the technological corporations, that are pushing the cities by searching new markets for their products so called "smart". This is one of the possibilities for large corporations to establish themselves as "smart" product market leaders, that at the same time attract new investors. Via economic, transport, infrastructure or other city fields ICT product corporations create commercial technological packages (intelligent traffic lights, sensors, self-driven cars, autonomous busses, waste 
management, traffic management, etc.) for smart cities. It is important to understand that in the concept of smart cities, there is no one recipe, via technologies or smart management. The smart city concept is much more complex and has a lot of interdisciplinary elements to cover. Therefore, there is no one specific field that can turn cities in to smart cities; all elements that create city should be implementing their smartness in to complete city as a smart city.

Many smart city projects use technologies for synchronising the urban processes. The overall smart city concept from urban design perspective is driven by resource efficiency, management, distribution of services and smart community participation. However, it is very little payed attention to the smart elements implementation via city design process and its adaptation and durability. Modern technologies are focused on the mass consumption, usage, mono design, unification. In this way technologies eliminate the essential urban design principles of the place and unique character. It is important to rethink smart cities via technological ICT's implementation, their adaptation, durability and resilience of cities.

To conclude, smart cities concept according to [3], involve a great variant of aspects such as environmental, social, political and technological, by which cities try to increase energy efficiency, efficient development, mobility, manage infrastructure and this refers to the terms: sustainability, ecology and management that we use in economy, urban and landscape design, etc. Despite the fact, that smart cities are perceived and seen as more generic and uniform by their approach to urban and landscape design, the present examples of smart cities developed viatechnological, economic, political and other ways.

\section{References}

1. Alberto, V. Smart mentality: The Smart City as Disciplinary Strategy. Urban Studies, 2014, Vol. 51(5), p.883-898.

2. Albino, V., Berardi, U. \& Dangelico, R.M. Smart Cities: Definitions, Dimensions, Performance, and Initiatives. Journal of Urban Technology, 2015, Vol. 22(1), p. 3-21.

3. Attmann, O. Green Architecture (Greensource Books): Advanced Technolgies and Materials. New York: McGrawHill Education, 2009.

4. Batty, M. The computable city. International Planning Studies, 1995, Vol. 2 p. 155-173.

5. Bruhns, H. Intelligence about our environment. In: Intelligent Environments Spatial Aspects of the Information Revolution. Droege, P. (ed.). Amsterdam: Elsevier, 1997, p. 260-294. b.V. doi:10.1016/B978-044482332-8/50019-6.

6. Butlin, J. Our Common Future. By World Commission on Environment and Development. London: Oxford University Press, 1987. 383 p.

7. Fakiri, I. The Interpretation of Landscape - Strategies Towards Smarter Cities. In: Proceedings of the 5th International Conference on Smart Cities and Green ICT Systems (SMARTGREENS 2016), 2016, p. 111-116

8. Gabrys, J. Programming environments: environmentality and citizen sensing in the smart city. Environment and Planning: Society and Space, 2014, Vol. 32, p. $30-48$

9. Giffinger, R. et al., Smart cities Ranking of European medium-sized cities [online 14.07.2018.]. www.smartcities.eu/download/smart_cities_final_report.pdf.

10. Glasmeier, A. K., Nebiolo, M. Thinking about Smart Cities: The Travels of a Policy Idea that Promises a Great Deal, but So Far Has Delivered Modest Results. Sustainability, 2016, Vol. 8, p.1-11.

11. Goodall, B. The Penguin Dictionary of Human Geography. Harmondsworth, Middlesex: Penguin Books, 1987.

12. Gruen, A. Smart Cities: the need for spatial intelligence. Geo-Spatial Information Science, 2013, Vol. 16 (1), p. 3-6.

13. Harvey, D. From managerialism to entrepreneurialism: the transformation in urban governance in late capitalism, Geografiska Annaler: Series B, Human Geography, 1989, Vol. 71(1), p. 3-17.

14. Hembd, J. \& Silberstein, J. Sustainable Communities: Sustainability and Community Development. In: Introduction to Community Development: Theory, Practice, and Service-learning. J. W. Robinson, G. P. Green (eds.). SAGE, 2011, p. 261-277.

15. Hung P., and Peng K. Green-energy, water-autonomous greenhouse system: an alternative-technology approach towards sustainable smart-green vertical greening in smart cities. International review for spatial planning and sustainable development, 2017, Vol. 1 (5) p. 55-70.

16. Jucevičius R., Liugailaitė-Eadzvickienė L. Intelektiskojo miesto koncepcija. Sumanioji socialine Sistema. Vilnius, KTU leidykla, 2017, p. 168-192

17. Kolokotsa, D. The role of Smart Grids in the Building Sector. Energy and Buildings. [online 10.07.2018.], http://doi.org/10.1016/j.enbuild.2015.12.033

18. Komninos, N. Intelligent Cities: Innova- tion, Knowledge Systems and Digital Spaces. London: Routledge, 2002. $307 \mathrm{p}$.

19. Koutra, S., Becue, V. and Ioakimidis, C. From the 'Smart Ground' to the 'Smart City' - An Analysis of Ten European Case-studies. In: Proceedings of the 5th International Conference on Smart Cities and Green ICT Systems (SMARTGREENS 2016), 2016, p. 105-110.

20. Teleports and the intelligent city. Lipman A.D., Sugarman A.D \& Cushman R.F. (eds). Communication booknotes (vol. 18). Homewood, Illinois: Dow Jones-Irwin, 1986. 411 p.

21. Lombardi, P., Giordano, S., Farouh, H. and Yousef, W. Modelling the smart city performance. Innovation: The European Journal of Social Science Research, 2012, Vol. 25(2), p. 137-149.

22. Punter, J. Carmona, M. The design dimension of planning: theory, content and best practice for design policies. London; New York: E \& FN Spon, 1997. 399 p. 
23. Rasha, F. E. Smart Cities, Sustainable Cities, or Both? A Critical Review and Synthesis of Success and Failure Factors. In: Proceedings of the 6th International Conference on Smart Cities and Green ICT Systems, 2017, p. 250-257.

24. Schmitt-Ehgner, P. The concept of region: theoretical and methological notes on its reconstruction. Journal of European Integration, 2002, Vol. 24, p. 179-200.

25. Sinkiene, J. Sumanusis miestas ir regionas. Sumanioji socialine sistema. KTU leidykla, Vilnius, 2017, p. 150-165.

26. Winter, S. Spatial intelligence: ready for a challenge? Spatial Cognition and Computation: An Interdisciplinary Journal, 2009, Vol. 9(2), p. 138-151.

INFORMATION ABOUT AUTHOR:

Skirmante Mozuriunaite - Doctor of Humanities, Theory and History of Arts, Vilniu Gediminas technical university. Associate Professor at the department of Urban Design, Vice dean for studies at the Vilnius Gediminas technical university, Faculty of Architecture, Traku Str. 1, LT-01132, Vilnius, Lithuania. E-mail: skirmante.mozuriunaite@vgtu.lt.

Kopsavilkums. Gudrās pilsētas nav jauna parādība un tā ir starpdisciplinārs jēdziens, kas kḷvis populārs sauklis mūsdienu pilsētām. Tomēr, ir pārsteidzoši maz akadēmisko pētījumu pilsētplānošanā. Gudrās pilsētas definīcija ir līdzīga inteliǵentai, radošai, ilgtspējīgai vai dzīvojamai pilsētai, kas šḳiet tiek uzskatīta par vārdu spēles daḷu. Vairumā tehnoloǵiju un sociālo zinātṇu rakstos gudrās pilsētas attiecinātas uz gudru pilsētas vadīšanu un attīstību caur tehnoloǵijām un infrastruktūru. Balstoties literatūras apskatā, ir vairāki pilsētas gudrumu ietekmējošie faktori, kā, piemēram, tehnologiijas, cilvēki un sabiedrības, ekonomiskā pārvalde, plānošana un infrastruktūra. Kopumā ir maz informācijas un pētījumu par pilsētvides dizaina principiem un instrumentiem gudro pilsētu veidošanā un ieguldījumu to gudrumā. Svarīgākais ir noskaidrot pilsētas dizaina, plānošanas un ainavas dizaina nozīmīgumu gudrās pilsētas kontekstā un arī pretēji. Raksta mērķis ir pārskatīt gudrās pilsētas jēdzienu no pilsētvides dizaina skatupunkta, lai noskaidrotu nozīmīgus saskares punktus, sasaistes un lomu gudrās pilsētas veidošanā pilsētvides dizainam, plānošanai un ainavas dizainam. Tas vestu pie pamatprincipiem Eiropas gudrajām pilsētām ilgtspējības veidošanā, racionālā pilsētas augšanā un labākā pilsētas ainavā. 